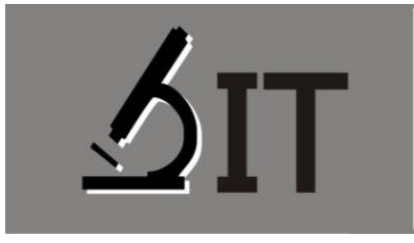

p-ISSN : 2597-8977

e-ISSN : 2597-8985

Achmad Zulkifli Hasan

SMPN 1 Lilirilau Kab. Soppeng

Ramlawati

Universitas Negeri Makassar

Ratnawaty Mamin

Universitas Negeri Makassar
JIT 2 (2) (2019) 12-17

JURNAL IPA TERPADU

http://ojs.unm.ac.id/index.php/ipaterpadu

\section{PENGARUH MODEL PEMBELAJARAN GUIDED INQUIRY TERHADAP KETEREMPILAN PROSES SAINS PESERTA DIDIK KELAS VII SMP NEGERI 2 LILIRILAU (Studi Pada Pada Materi Pokok Interaksi Makhluk Hidup Dengan Lingkungan)}

Abstrak: Penelitian ini bertujuan untuk mendeskripsikan keterampilan proses sains peserta didik yang dibeajarkan melalui model pembelajaran guided inquiry dan yang dibelajarkan dengan model pembelajaran konvensional, serta untuk mendeksripsikan apakah keterampilan proses sains peserta didik yang dibelajarkan dengan model pembelajaran Guided inquiry lebih tinggi dari model pembelajaran konvensional di kelas VII SMP Negeri 2 Lilirilau tahun ajaran 2016/2017. Penelitian ini adalah penelitian eksperimen semu dengan menggunakan desain Nonequivalent Kontrol Group Design. Populasi dalam penelitian ini adalah peserta didik kelas VII SMP Negeri 2 Lilirilau tahun ajaran 2016/2017 yang terdiri dari 5 kelas dengan jumlah 105 orang dan sampel dipilih dengan menggunakan double random sampling. Pengolahan data hasil penelitian ini menggunakan teknik analisis deskriptif untuk menggambarkan keterampilan proses sains peserta didik dan teknik analisis inferensial untuk menguji hipotesis penelitian. Berdasarkan analisis deskriptif didapatkan bahwa rata-rata keterampilan proses sains peserta didik yang dibelajarkan dengan menggunakan model pembelajaran Guided inquiry berada pada kategori tinggi sedangkan nilai rata-rata keterampilan proses sains peserta didik yang dibelajarkan dengan model konvensional berada pada kategori sedang masing-masing. Hasil analisis inferensial menunjukkan bahwa terdapat pengaruh model pembelajaran Guided inquiry terhadap keterampilan proses sains peserta didik kelas VII SMP Negeri 2 Lilirilau pada taraf nyata $\alpha=0,05$.

Kata Kunci: Model pembelajaran guided inquiry, Keterampilan proses sains.

Abstract: This research aims to know student's science process skills who are taught with Guided inquiry model and conventional learning model, as well as the student's Science process skills significant differences between students who are taught with the Guided inquiry learning model and conventional learning model in seventh grade SMP Negeri 2 Lilirilau academic year 2016/2017. This research is true experimental design with Nonequivalent Control group design. The population in this research are the students of seventh grade SMP Negeri 2 Lilirilau academic year 2016/2017 consist of five grade with 105 students and a double randomly selected sample. The results of this research data processing using two statistical techniques, namely descriptive analysis to describe the science characteristics of science process skills students and inferential analysis techniques to test the research hypothesis.

*) Correspondence Author: Achmadzul14@gmail.com 
Based on descriptive analysis found that the average Science Process skills of student are taught with guided inquiry model in high categorized, while the average score who are taught with the conventional model in middle categorized. Inferential analysis results showed that there were significant no differences in the Science process skills between students taught by Guided inquiry model and are taught by using conventional model on a significance level of $\alpha=0.05$.

Keyword: Guided inquiry learning model, Science process skill

\section{PENDAHULUAN}

Pendidikan merupakan kunci untuk semua kemajuan dan perkembangan yang berkualitas, sebab dengan pendidikan manusia dapat mewujudkan semua potensi dirinya baik sebagai pribadi maupun sebagai warga masyarakat. Oleh karena itu, dalam rangka mewujudkan potensi diri menjadi multi kompetensi manusia harus melewati proses pendidikan yang diimplementasikan dalam proses pembelajaran. Dengan demikian, proses pembelajaran hendaknya bisa mengembangkan kemampuan dan membentuk watak manusia sehingga tercipta pendidikan yang berkualitas.

Belajar merupakan proses interaksi edukatif yang terikat pada tujuan, terarah pada tujuan, dan dilaksanakan khusus untuk mencapai tujuan/ Melalui proses belajar, yang diharapkan berhasil mencapai tujuan adalah peserta didik itu sendiri. Oleh karena itu, hal terpenting dalam pembelajaran adalah peserta didik. Peserta didiklah yang diharapkan berinteraksi dengan bahan ajar itu, mengolahnya, dan merefleksikannya sehingga tujuan instruksional yang telah ditetapkan dapat dicapai secara optimal.

Berdasarkan hasil observasi yang telah dilakukan di SMP Negeri 2 lilirilau pada tanggal

9 juni 2016, diperoleh informasi, bahwa pembelajaran IPA yang berlangsung masih didominasi oleh guru serta kurang bervariasi. Proses pembelajaran lebih sering menggunakan metode ceramah. Pembelajaran yang berlangsung masih konvensional dengan latihan soal, sehingga kurangnya kesempatan peserta didik untuk memiliki pengalaman belajar yang nyata dan aktif. Hal ini berdampak pada proses pembelajaran yang diterapkan belum dapat mencapai tujuan pembelajaran secara maksimal. Kondisi ini berdampak pada pencapaian KKM bernilai 70 masih kurang.

Salah satu model pembelajaran yang dapat digunakan untuk memperoleh hasil belajar yang baik pada karakteristik kompetensi keterampilan proses sains peserta didik adalah model pembelajaran Guided inquiry. Pembelajaran inkuiri terbimbing merupakan pembelajaran kelompok dimana peserta didik diberi kesempatan untuk berfikir mandiri dan saling membantu dengan teman yang lain.

Pembelajaran inkuiri terbimbing membimbing peserta didik untuk memiliki tanggung jawab individu dan tanggung jawab dalam kelompok atau pasangannya (wiwin, 2013). Berdasarkan keadaan peserta didik yang diamati di sekolah SMP Negeri 2 Lilirilau, maka model pembelajaran Guided inquiry merupakan suatu cara yang efektif , karena pada proses pembelajaran ini mampu memberi kesempatan kepada peserta didik untuk memiliki pengemalam belajar yang nyata dan aktif sehingga peserta didik terlatih dalam memecahkan masah sekaligus membuat keputusan.

Pembelajaran inkuiri terbimbing merupakan model pembelajaran yang berlandaskan pandangan Konstruktivisme yang memandangbahwa pembelajaran mengkonstruksi sendiri pengetahuannya. Pada pembelajaran Inkuiri terbimbing peserta didik mendapat petunjuk-petunjuk seperlunya, dapat berupa pertanyaan pertanyaan yang bersifat membimbing, Kemudian sedikit 
demi sedikit bimbingan dikurangi hingga peserta didik dapat bekerja mandiri dalam penyelesaian masalah (Tangkas, 2012).

Pembelajaran inkuiri terbimbing, guru mengajukan masalah dan peserta didik menentukan proses dan solusinya. Pembelajaran inkuiri terbimbing sangat penting diterapkan: 1) menginginkan peserta didik menjadi seorang yang literasi sains/teknologi dan dapat memecahkan masalah, sehingga peserta didik harus berpartisipasi secara aktif pada jenjang yang sesuai dalam aktivitas sains dengan bantuan dan bimbingan guru, 2) pembalajaran ini sangat penting bagi peserta didik yang masih muda (peserta didik kelas rendah), karena mereka membutukan pengalaman belajar secara konkret. Redhana dalam (Neka, 2015).

Dalam pembelajaran inkuiri Terbimbing sebagai pusat pembelajaran adalah peserta didik, dimana peserta didik dituntut untuk bertanggung jawab atas pendidikan yang mereka jalani serta diarahkan untuk tidak selalu bergantung pada guru. Pada pembelajaran Inkuiri Terbimbing peserta didik menjadi lebih termotivasi Ketika mereka belajar menemukan sesuatu oleh dirinya sendiri, dari pada mendengarkan apa yang dikatakan guru. Mereka belajar melakukan aktivitas dengan otonomi dan menjadi yang inner-directed. Bagi peserta didik yang inner- directed, penghargaan merupakan penemuan itu sendiri. Peserta didik belajar memanipulasi lingkungan lebih aktif. Mereka mencapai mencapai kepuasan dari pemecahan masalah, Bruner percaya bahwa peserta didik menerima sensasi Intelektual yang memuaskan suatu penghargaan intrinsic atau kepauasan sendiri (Tangkas, 2012).

Langkah-langkah pembelajaran inkuiri terbimbing menurut Wiwin (2013) yaitu: (1) Merumuskan masalah guru membimbing peserta didik menentukan suatu masalah yang terkait dengan pelajaran yang disampaikan, kemudian peserta didik memikirkan sendiri jawabannya; (2) Mengajukan hipotesis, guru membimbing peserta didik menemukan jawaban sementara atas masalah yang ditemukan; (3) Mengumpulkan data, peserta didik melakukan eksperimen sederhana; (4) Menguji data berdasarkan data yang ditemukan, peserta didik menguji hasil eksperimen dengan fakta-fakta dan teori yang terkait; (5) Membuat kesimpulan peserta didik mempresentasikan hasil diskusinya di depan kelas dan membuat kesimpulan.

Menurut Rezba dalam (Delismar, 2013) keterampilan dasar proses adalah keterampilan yang digunakan ketika pembelajaran sains. Dari pengertian keterampilan proses tersebut, terdapat beberapa point yang dilakukan peserta didik dalam belajar sains, yaitu pengamatan, prediksi, menyimpulkan, mengklasifikasi, mengkomunikasikan, dan mengukur. Dengan mengkombinasikan kemampuan proses yang terintegrasi dengan dasar kemampuan proses sains, guru dapat membuat suasana kelas dimana peserta didik mengeksplorasi, menginvestigasi, dan menemukan. Ketika peserta didik belajar mengintegrasikan kemampuan proses, mereka menyelidiki bagaimana sesuatu bekerja dan mereka mencari jawaban dari pertanyaan mereka sendiri dengan merancang dan melakukan eksperimen. Integrasi kemampuan proses sains mencakup mengidentifikasi, mengkonstruk hipotesis, menganalisis investigasi, mentabulasi dan membuat grafik data, menjelaskan variabel, merancang investigasi, dan bereksperimen.

Tujuan melatih keterampilan proses pada pembelajaran IPA, yaitu meningkatkan motivasi dan hasil belajar peserta didik, karena dalam melatih peserta didik dipacu untuk berpartisipasi secara aktif dan efisien dalam belajar, menuntaskan hasil belajar peserta didik secara serentak. Peserta didik mudah memahami konsep-konsep yang rumit dan abstrak jika disertai dengan contoh-contoh konkrit merupakan salah satu alasan yang melandasi perlunya diterapkan keterampilan proses sains (Wiwin, 2013).

Keterampilan proses sains dalam pembelajaran perlu diimplementasikan mengingat bahwa perkembangan ilmu pengetahuan berlangsung semakin cepat sehingga tak mungkin lagi diajarkan semua fakta dan konsep kepada peserta didik, apabila fakta dan konsep diinformasikan secara verbal, akibatnya para peserta didik memiliki banyak pengetahuan, tetapi tidak dilatih untuk menemukan pengetahuan, mengembangkan ilmu, menemukan konsep, atau sesuatu prinsip (Tawil, 2014). 
Permasalahan yang dikaji dalam penelitian ini meliputi: (1) Seberapa tinggi tingkat keterampilan proses sains peserta didik setelah dibelajarkan melalui model pembelajaran Guided inquiry di SMPN 2 Lilirilau tahun ajaran 2016/2017?. (2) Seberapa tinggi tingkat Keterampilan proses sains peserta didik setelah dibelajarkan melalui model pembelajaran konvensional di SMPN 2 Lilirilau tahun ajaran 2016/2017?. (3) Apakah keterampilan proses sains peserta didik yang dibelajarakan dengan model pembelajaran Guided inquiry lebih tinggi dari model pembelajaran konvensional di SMPN 2 Lilirilau tahun ajaran 2016/2017?

\section{METODE}

Jenis penelitian Eksperimental-Semu. Populasi dalam penelitian ini adalah peserta didik kelas VII pada SMP Negeri 2 Liliriaja semester genap tahun pelajaran 2016/2017. Pengambilam sampel dilakukan secara acak menggunkan teknik (Double Sampling Random), sehingga diperoleh sampel kelas eksperimen pada kelas VII C dan kelas kontrol pada kelas VII D di SMP Negeri 2 Liliriaja pada semester genap tahun pelajaran 2016/2017 yang mempunyai kemampuan yang berbeda-beda.

Penelitian ini merupakan jenis penelitian quasi- eksperimen (quasy experimental) pretestpostest dengan rancangan Nonequivalent control grup. Oleh karena itu pelaksanaannya menggunakan dua kelas yaitu kelas eksperimen yang diterapkan model pembelajaran inkuiri terbimbing dan kelas kontrol dengan pembelajaran konvensional. Penelitian ini menggunakan teknik analisis data statistic deskriptif dan statistik inferensial pada taraf signifikan $\alpha=5 \%$.

\section{HASIL DAN PEMBAHASAN}

Analisis data deskriptif keterampilan proses sains peserta didik kelas eksperimen dan kelas kontrol ditunjukkan pada Tabel 1.

Tabel 1. Deskripsi Nilai Keterampilan Proses Sains Kelas Eksperimen dan Kelas Kontrol

\begin{tabular}{ccccc}
\hline \multirow{2}{*}{ Data } & \multicolumn{2}{c}{ Kelas Eksperimen } & \multicolumn{2}{c}{ Kelas Kontrol } \\
\cline { 2 - 5 } & Pretest & Postest & Pretest & Postest \\
\hline Ukuran sampel & 21 & 21 & 21 & 21 \\
Nilai tertinggi & 66 & 96 & 52 & 84 \\
Nilai terendah & 8 & 72 & 8 & 40 \\
Nilai rata-rata & 37,80 & 84,47 & 31,61 & 65,71 \\
Standar deviasi & 18,80 & 7,48 & 12,50 & 13,05 \\
\hline
\end{tabular}

Berdasarkan data pada Tabel 1 dapat dilihat bahwa rata-rata nilai pretes pada kelas eksperimen dan kelas kontrol masing-masing adalah 37.80 dan dan 31.61. Sementara itu, posttest untuk kelas eksperimen adalah 84,47 sedangkan posttest untuk kelas kontrol adalah 65.71. Berdasarkan data tersebut terlihat bahwa rata-rata nilai pretes kelas eksperimen sedikit lebih besar dibandingkan kelas kontrol. Namun pada rata - rata nilai Postest kelas eksperimen lebih besar dari kelas kontrol. 
Berdasarkan hasil analisis data $\mathrm{N}$-gain untuk mengetahui selisih nilai posttest dan Pretest dapat dilihat pada Tabel 2.

Tabel 2. Kriteria N-Gain Kelas Eksperimen dan Kelas Kontrol

\begin{tabular}{ccccc}
\hline \multirow{2}{*}{ Kriteria } & \multicolumn{2}{c}{ Frekuensi } & \multicolumn{2}{c}{ Persentase (\%) } \\
\cline { 2 - 5 } & Kelas eksperimen & Kelas kontrol & Kelas eksperimen & Kelas kontrol \\
\hline Tinggi & 14 & 2 & 66.66 & 9.52 \\
Sedang & 7 & 16 & 33.33 & 76.19 \\
Rendah & 0 & 3 & 0.00 & 14.28 \\
\hline
\end{tabular}

Berdasarkan tabel diatas maka dapat disimpulkan bahwa N-gain pada kelas eksperimen lebih dominan berada pada kategori tinggi dari kelas kontrol. Ketercapaian indikator keterampilan proses sains pada pretest diketahui bahwa rata - rata dikelas eksperimen $34.68 \%$ dengan kategori sedang dan kelas kontrol rata - rata yang diperoleh 31.98\% dengan kategori sedang. Persentase pencapain indikator paling tinggi di kelas eksperimen pada keterampilan proses sains adalah indikator mengelompokkan dan klasifikasi dengan persentase yang di capai pada kelas eksperimen yaitu sebesar $88,57 \%$. Hal ini terlihat jelas dalam LKPD yang mereka kerjakan serta hasil soal Posttest yang telah dikerjakan, di mana peserta didik mencatat setiap pengamatan, mencari perbedaan, membandingkan serta mengelompokkan secara tepat. Selain itu, pada saat melakukan presentasi, diberikan kesempatan pada satu kelompok untuk mempresentasikan hasil percobaan mereka. Setiap kelompok mampu saling bertukar informasi mengenai hasil percobaan berdasarkan pengelompokkan dan klasifikasi yang telah dikerjakan.

Persentase pencapain indikator paling tinggi di kelas kontrol pada keterampilan proses sains adalah indikator mengkomunikasikan dengan persentase yang di capai pada kelas kontrol yaitu sebesar $73.81 \%$. Hal ini terlihat jelas dalam pada saat melakukan presentasi, diberikan kesempatan pada satu kelompok untuk mempresentasikan tugas mereka sedangkan kelompok lain menanggapi dan memberikan pertanyaan. Setiap kelompok mampu menanggapi dan memberikan pertanyaan pada kelompok penyaji. Hal ini membuktikan bahwa peserta didik pada kelompok kontrol cukup terlatih berkomunikasi.

Pada kelas eksperimen, persentasen indikator keterampilan proses sains yang paling rendah adalah indikator merumuskan masalah. Di mana pada kelas eksperimen, dapat memberikan sebuah rumusan masalah berdasarkan wacana yang diberikan. Namun, rumusan masalah yang peserta didik buat tersebut tidak tepat meskipun telah di berikan penjelasan di awal pertemuan.

Pada kelas kontrol, persentase Pencapain indikator paling rendah pada keterampilan proses sains adalah indikator Merancang eksperimen dengan persentase yang di capai yaitu sebesar 61.9\%. Hal ini terlihat jelas dalam hasil Posttest mereka kerjakan. Pada kelas ini model pembelajaran yang digunakan yaitu model pembelajaran konvensional dimana pembelajaran berpusat pada pendidik yang hanya menjelaskan dengan ceramah didepan kelas sehingga peserta didik masih kurang memahami cara merancang suatu percobaan. Hal ini membuktikan bahwa peserta didik pada kelas kontrol masih kurang dalam merancang eksperimen.

Penelitian ini juga bertujuan untuk melihat keterampian proses sains para peserta didik. Nilai keterampilan proses sains masing-masing kelompok sampel akan dikategorikan menjadi tinggi dan rendah yang dilihat berdasarkan rata-rata nilai keterampilan proses. 


\section{KESIMPULAN}

Hasil penelitian ini dapat disimpulkan sebagai berikut:

1. Keterampilan proses sains peserta didik kelas VII SMP Negeri 2 Lilirilau tahun ajaran 2016/2017 yang diajar menggunakan model pembelajaran guided inquiry berada pada kategori tinggi.

2. Keterampilan proses sains peserta didik kelas VII SMP Negeri 2 Lilirilau tahun ajaran 2016/2017 yang diajar menggunakan model pembelajaran konvensional berada pada kategori sedang.

3. Keterampilan proses sains peserta didik yang dibelajarkan dengan model pembelajaran guided inquiry lebih tinggi dari model pembelajaran konvensional kelas VII SMP Negeri 2 Lilirilau tahun ajaran 2016/2017.

\section{DAFTAR PUSTAKA}

Delismar, R. A. (2013). Peningkatan Kreativitas dan Keterampilan Proses sains Peserta didik melalui Penerapan Model Grup Investigation. Edu-Sains. Vol. 1 No. 2.

Neka, I. K. (2015). Pengaruh model pembelajaran inkuiri terbimbing berbasis lingkungan terhadap keterampilan berpikir kreatif dan penguasaan konsep IPA Kelas V SD Gugus VIII Kecamatan Abang. E-Journal Program Pascasarjana Universitas Pendidikan Ganesha Program Studi Pendidikan Dasar.

Paidi. (2005). Peningkatan Scientific Skill Peserta didik Melalui Implementasi Metode Guided Inquiry Pada Pembelajaran Biologi. FMIPA: Universitas Negeri Yogyakarta.

Tangkas, I. M. (2012). Pengaruh implementasi model pembelajaran inkuiri termbimbing terhadap kemampuan pemahaman konsep dan keterampilan proses sains peserta didik SMA $X$ Amplapura.

Tawil, M. (2014). Keterampilan Proses Sains dan Implementasinya dalam Pembelajaran IPA. Makassar: Badan Penerbit UNM.

Wiwin, A. (2013). Penerapan pembelajaran inkuiri terbimbing terhadap keterampilan proses sains dasar pada pelajaran biologi peserta didik kelas VIII SMP Negeri 7 Surakarta. Pendidikan Biologi. Vol.5 No. 1. 81-95.

\section{Achmad Zulkifli Hasan}

Guru mata pelajaran IPA di SMPN 1 Lilirilau Kabupaten Soppeng, dapat dihubungi melalui pos-el: achmadzul14@gmail.com

\section{Ramlawati}

Dosen Program Studi Pendidikan IPA FMIPA UNM, aktif melakukan penelitian pada bidang Pendidikan IPA.

\section{Ratnawaty Mamin}

Dosen Program Studi Pendidikan IPA FMIPA UNM, aktif melakukan penelitian pada bidang Pendidikan IPA. 